\title{
MIĘDZYNARODOWA KONFERENCJA NAUKOWA \\ „VYSKUPAS ANTANAS BARANAUSKAS: ASMENYBE IR APLINKA” \\ („BISKUP ANTONI BARANOWSKI: OSOBOWOŚĆ I ŚRODOWISKO”) \\ WILNO, 21-22 LISTOPADA 2002 ROKU
}

Przypadająca 26 listopada 2002 r. setna rocznica śmierci bpa Antoniego Baranowskiego była okazją do zorganizowania konferencji naukowej poświęconej temu wybitnemu pasterzowi, uczonemu i poecie. Sesję naukową zorganizował Instytut Historii Litwy razem z Litewską Katolicką Akademią Nauk. Rozpoczęła się ona Mszą św. koncelebrowaną w bazylice katedralnej w Wilnie (w kaplicy św. Kazimierza) pod przewodnictwem biskupa z Telsz dr. Jonasa Boruty, prezesa Litewskiej Katolickiej Akademii Nauk. Obrady natomiast miały miejsce w gmachu Instytutu Historii Litwy (ul. Kraziu 5).

Wypada podać najważniejsze dane z życia bpa Baranowskiego (po litewsku Antanas Baranauskas). Urodził się on 17 I 1835 r. w miasteczku Onikszty w powiecie wiłkomierskim. Ukończył Seminarium Duchowne w Worniach, a następnie Akademię Duchowną w Petersburgu, w której też jakiś czas pracował jako profesor, kapelan i bibliotekarz. W 1867 r. został mianowany profesorem Seminarium Duchownego w Kownie. Potem był jego wicerektorem, tu otrzymał nominację na kanonika, a następnie prałata kapituły katedralnej żmudzkiej, a w 1883 r. papież Leon XIII prekonizował go na biskupa sufragana diecezji żmudzkiej. W 1997 r. został biskupem ordynariuszem diecezji sejneńskiej. Zmarł 26 XI 1902 r. i pochowany został w katedrze sejneńskiej. Jako pasterz działał w duchu pojednania polsko-litewskiego.

Zaznaczył się on nie tylko jako kapłan i biskup, ale także jako poeta, matematyk, filozof i lingwista. $\mathrm{Z}$ utworów poetyckich najbardziej znany jest „Anyksciu silelis” - „Borek oniksztyński” (niektórzy tłumaczą „Lasek oniksztyński”), zaliczany do klasyki literatury litewskiej. Napisał wiele wierszy i pieśni religijnych. Z dzieł matematycznych i filozoficznych wypada wymienić książkę „O wzorach służących do obliczania liczby liczb pierwotnych, nie przekraczającej danej granicy”, wydanej przez Akademię Umiejętności w Krakowie 
w 1895 r. i „O progresji transcendentalnej, oraz o skali i siłach umysłu ludzkiego" (Warszawa 1897).

Sympozjum otworzył dr Dariusz Staliunas, wicedyrektor Instytutu Historii Litwy, który wprowadził w tematykę i powitał zgromadzonych uczestników. Pierwszy referat wygłosił Vytautas Jogela na temat „Antoni Baranowski w Akademii Duchownej w Petersburgu”. Następnie bp Boruta w swoim wystąpieniu odpowiadał na postawione przed siebie pytanie czy idee bpa Antoniego Baranowskiego doczekały się swego wypełnienia. Biskupa Baranowskiego jako matematyka przedstawił prof. Jonas Kubilius, były długoletni rektor Uniwersytetu Wileńskiego. Podkreślił on, że Baranowski był twórcą litewskich terminów matematycznych, których szereg przetrwało do dziś. Niektóre jego dzieła matematyczne były drukowane w Krakowie i Warszawie, ale większość pozostało w rękopisach.

Trudno omawiać wszystkie wygłoszone referaty. W ciągu dwóch dni wygłoszono ich dziewiętnaście. Dotyczyły różnych dziedzin życia i działalności bpa Baranowskiego. Dalia Ciocyte wygłosiła referat na temat Boga i narodu w poematach Antoniego Baranowskiego, natomiast prof. Vanda Zekoniene przedstawiła koncepcję ekologii według „Borku oniksztyńskiego”, zaś Paulius Sybacius podjął się trudnego zadania ukazania Europy widzianej oczami A. Baranowskiego. Prof. Egidijus Aleksandravicius poruszył problem „lenkomaniji”, zarzucanej Baranowskiemu przez liderów litewskiego ruchu narodowego. Wydaje się, że odpowiednikiem litewskiego terminu „lenkomanija” byłby zwrot „polakomania”. Bronius Makauskas wgłosił referat na temat Antoniego Baranowskiego jako "niezrozumianego intelektualisty i biskupa", a Algimantas Katilius zwrócił uwagę na stosunek bpa Baranowskiego do wprowadzania przez władze carskie do Seminarium Duchownego wykładu przedmiotów w języku rosyjskim. Aldona Prasmantaite dała w swoim wystąpieniu spojrzenie na Pismo św. w kontekście katolickiej kultury Litwy XIX w., uwzględniając przede wszystkim przekłady i tłumaczy. Darius Staliunas ukazał perypetie związane z wprowadzaniem przez władze carskie do szkół wykładu katolickiej wiary w języku rosyjskim. Krzysztof Buchowski przedstawił stosunki polsko-litewskie na Ziemi Sejneńskiej na przełomie XIX i XX w., natomiast Vilma Zaltauskaite zajęła się problematyką stosunków władz rosyjskich ze Stolicą Apostolską w ostatnich dziesiątkach lat XIX w. Piszący te słowa zaprezentował referat na temat rządów bpa Stefana Zwierowicza w diecezji wileńskiej w świetle pamiętników ks. Jana Kurczewskiego. Warto tu zaznaczyć, że bp Zwierowicz rządził w Wilnie w tym samym czasie co bp Baranowski w Sejnach. Konferencję podsumowała i zakończyła Regina Laukaityte z Instytutu Historii Litwy. 
W tej konferencji naukowej wzięli udział przedstawiciele wielu ośrodków naukowych Litwy: Uniwersytetu Wileńskiego, Uniwersytetu im. Witolda Wielkiego w Kownie, Uniwersytetu Gospodarstwa Wiejskiego w Kownie, Uniwersytetu w Kłajpedzie, Uniwersytetu w Szawlach. Najliczniej reprezentowany był Instytut Historii Litwy w Wilnie. Litewską Katolicką Akademię Nauk reprezentował biskup telszewski Jonas Boruta. Z Polski było trzech historyków: Bronisław Makowski z Warszawy oraz Krzysztof Buchowski i ks. Tadeusz Krahel z Białegostoku.

Należy wyrazić uznanie organizatorom tej sesji naukowej, że w ten sposób uczcili pamięć bpa Baranowskiego w setną rocznicę jego śmierci i przypomnieli tak zasłużonego dla Kościoła na Litwie i w Polsce pasterza oraz przybliżyli jego zasługi dla kultury litewskiej.

ks. Tadeusz Krahel 